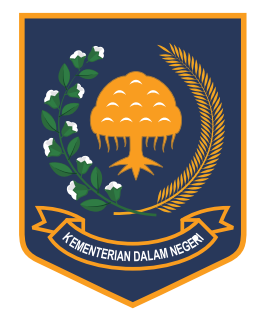

Jurnal Bina Praja 10 (1) (2018): 147-157

Jurnal Bina Praja

e-ISSN: 2503-3360 | p-ISSN: 2085-4323

Accreditation Number

735/AU2/P2MI-LIPI/04/2016

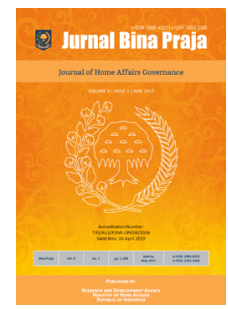

http://jurnal.kemendagri.go.id/index.php/jbp/index

\title{
ACCElERATion Model of Child-FriEndly City/District in LAMPUng Province
}

\author{
Noverman Duadji ${ }^{1,}{ }^{*}$, Novita Tresiana ${ }^{2}$, Rahmah Dianti Putri ${ }^{3}$ \\ ${ }_{1,2,3}$ Institute for Research and Community Service of Lampung University (LPPM Unila) \\ Rectorate Building 5th Floor, Jl. Sumantri Brojonegoro No. 1 \\ Bandar Lampung 35145, Indonesia
}

Received: 4 February 2018; Accepted: 24 April 2018; Published online: 12 May 2018

DOI: $10.21787 / j b p .10 .2018 .147-157$

\begin{abstract}
Lampung Province has issued several children programs, but its implementation is still not maximal. Such conditions are possible because, in the context of the actors and substance, the KLA (Kota Layak Anak or Child-Friendly City) program still positions the local government as a single actor. The issue of children has not been the center of attention in the overall development policy. Sectoral, segmented, and structured children programs do not involve community potential. Such patterns and modeling are the products of top-down planning. That is, the location of the constraints is in the centralized model as the applied planning model. Related to this, hence more comprehensive, integrated methods, models and ways to achieve the objectives of KLA program of Lampung Province are required. The purpose of this study is to explain: 1) various central issues of child's problems, potentials of community institutional support and 2) model structure and phases of acceleration of city/district proper for children that can fulfill child rights, child protection, and child development. On the basis of the expected objectives, used the descriptive qualitative method. The research findings: 1) there are still many problems that occur in Lampung Province; 2) This study provides an overview of the potential of community institutions that have concerns about child issues and support for local government policy, but both are not synergistic, development programs are still implemented partially, segmented, sectoral, not yet integrated and less involving or inclusive to community potential. It can be concluded that the solution that can be developed is to build a collaborative planning model based on dialogue in multi-stakeholder forums as a strategic material for the city/ district in accordance with the implementation of the 3 stages which become the acceleration area of KLA.
\end{abstract}

Keywords: Child-Friendly, Collaboration, Planning, Multistakeholder Forum

\section{INTRODUCTION}

The normative juridical commitment to achieve the rights of children in Indonesia has been fought through various laws on children. First, Law no. 23 of 2002 on Child Protection, and then changed into Law no. 35 of 2014. Secondly, Law no. 11 of 2012 on Child Criminal Justice System. Thirdly, in the context of changes in the authority of local government, the protection of children is a mandatory business that has been submitted by the central government to the regional government as set forth in Law No. 32 of 2004 on Regional Government, following derivatives, namely Government Regulation No. 41 of 2007 on Regional Device Organizations and Government Regulation No. 38/2007 on the Division of Governmental Affairs between the Government,
Provincial Governments, and Regency/Municipal Governments. Fourth, the regional government already has the Agency for Women Empowerment, Child Protection, and Family Planning (BP3AKB). Specifically, for Lampung Province, the local government set the Mainstreaming of Child Rights (PUHA) as a perspective of child protection policy by integrating children's rights into every development activity and implementing it into the Child-Friendly City (KLA) development model.

The child-friendly city was originally a UNESCO initiative through a program called Growing Up City (Lynch, 1977). This activity itself is tested in four selected countries, namely Argentina, Australia, Mexico, and Poland. The purpose of the experiment is to know how a group of teenage children uses

\footnotetext{
* Corresponding Author

Phone : +62 81379646665

Email : novermanduadji@yahoo.co.id
} 
and assesses the surrounding spatial environment. The concept of the child-friendly city itself was introduced by UNICEF with the aim of creating a condition that aspires to children's rights through local government goals, policies, programs and structures ("The CFC Initiative," 2011)

Specifically, for Indonesia, the concept of ChildFriendly City/district is the first program introduced by the Ministry of Women's Empowerment and Child Protection of the Republic of Indonesia in 2005, through the Municipal Friendly-City Policy. For the reason of accommodating the district government, the term Child-Friendly City became the ChildFriendly City/District and then shortened to KLA. This policy illustrates that the KLA is an effort of the district/city government to accelerate the implementation of the Children Rights Convention (CRC) from the legal framework into definitions, strategies and development interventions, such as child-friendly policies, institutions, and programs. The normative juridical development of KLA is found in the World Fit for Children, Presidential Decree No. 36/1990 on the Ratification of the Convention on the Rights of the Child, the 1945 Constitution (Articles 28b, 28c), the National Program for Indonesian Children 2015, Law No. 34/2014 on Child Protection, and Candidate PPPA No. 2/2009 about the KLA Policy.

Lampung Province has issued several children programs, but its implementation is still not maximal. This is illustrated from the data of BPS Lampung Province (2016) which is directly related to the indicators of Child-Friendly City/district that need to get the attention of the local government, namely: a) exploitation and child abuse are still high $(5.7 \%)$; b) there are still many children who do not have birth certificates (21\%); c) the management of child-friendly information and child participation in development planning has not been conducted; and d) the lack of children institutional.

The above description is in accordance with the results of research by Duadji \& Tresiana (2017, p. 45) stating that "there are still many children dropping out of school, marriage at an early age, working children, without birth certificates, and the existence of children who are trapped in child trafficking, whether for sexual purposes or for any other purposes. To grow children, government should be expected to produce various action programs involving children and multi-stakeholders in a participative manner and in addition to the role of the policy stakeholders, especially related to institutions for children, colleges and advocacy institutions for children, and the communities that are an important part of the process and stages of the KLA program, so that the efforts, programs, and policies implemented are still sustained. Therefore, the new modeling and the sustainability of child- friendly city/district program (KLA) implementation is really urgent to be studied through research.

There are some previous research results that lie behind this study. First, the result of Lampung LKA study (2013, p. 37) stating that "there is a failure of KLA policy/program in Lampung Province where factually the local government has launched KLA model implementation in 2012, but the phenomenon of violation was more varied and complex to the rights of the children, the issue of protection and the child's growing space is still rife and emerging. This research only reveals the existence of program/policy failures but has not offered any method or model to accelerate the KLA program.

Second, the result of research from Tresiana (2015, p. 49) which states that: "(1) the failure of the transformation of children's rights is because the child's policy issues have not been able to become the center of attention in the overall development policy, so that the bias in its implementation and government bureaucracy has not been child responsive; and (2) the absence of awareness from policymakers or bureaucratic leaders on the importance of children's issues in the policies that are formulated ". This research is only limited to reveal the issue of children's rights and understanding of the actors towards children has not been a priority in the regional development planning, but there has been no offer of a planning model that can be used as an option to accelerate the KLA program.

Third, the research conclusion by Mahendra (2017, p. 104) that states "the implementation of the Child-Friendly City (KLA) policy, especially in the field of child-friendly health services, is good and is an interval of 2.77 (good) out of the maximum scale 4.00. But this research still suggests the need for scientific studies related to the policy of ChildFriendly City, both education and health, and also Child-friendly village ". Thus, the results of this study are still limited to the description of the success of the local government in running KLA program in the field of health.

Fourth, Bakar (2017, pp. 107-121) stated that "(1) the importance of the Governor's commitment as Regional Head to instruct all units and SKPD to allocate funds for the Integrated Service Centers for Women and Children Empowerment (P2TP2A) in West Sumatera Province, and (2) the need for the establishment of P2TP2A Limpapeh Rumah Nan Gadang that comes from various social activists' actions, so that they have a high sensitivity to the problems faced by women and children ". Although this research has placed important positions from various social activists' action, it still highlights the KLA's role, efforts, and programs from the internal side of local government. 
Fifth, a research by Sari (2015) stated the importance of the existence of institutions that are able to provide facilities for children to develop themselves and their creativity. This study presents nicely on the important role of institutions in the orientation of KLA programs designed by local governments but has not fully reviewed the substantive aspects and planning models run by local governments.

The five research findings described above, despite having different dimensions in terms of research focus, but have the same emphasis on the importance of the KLA program. Furthermore, the research on the implementation of Child-Friendly City in Lampung Province as conducted by Duadji (2017), when viewed from 3 parameters KLA program, is as follows: (1) city/district must have a playground for children; (2) the city should be free from violence against children, whether at home, school, and among the community; and (3) the city shall have a guarantee on the protection of child rights. The KLA program in Lampung Province has not been achieved. The reason is that KLA planning model, which is carried out by the government, is still very centralistic, linear (top down), and only makes city and children as the object of development. That is, the location of the constraints is in the applied planning model, the centralized model. This model no longer matches the current situation. Nonconformance is not only caused by the results of development far from what is expected but also not in accordance with national issues about democracy and reform and the current development. Therefore, the old ways become obsolete so that methods, models, and ways of the present are also needed. Parallel to this, Hamudy's study (2015) reinforces the need for similar paradigm on parenting and good cooperation among various parties who really want to promote the best interests of the child. Thus, the sides and substance of the planning become urgent to accelerate KLA program in the region and this research is an important thing to do.

Referring to BPS data of Lampung Province (2016) and research results as described above, it can be predicted that the KLA program in Lampung Province is still sluggish of potential programs. Thus, the movement and development of the KLA program in the province require serious attention from all parties. To ensure the movement and to develop things to the point or place to be expected, certainly needed a guidance assistance in the form of 'map' or 'GPS online'. Likewise, for a more complete and integrated model of KLA uang program to be accessed together with actors; and warns of multidisciplinary and interdisciplinary to be in compliance with related points at the KLA program. An effective acceleration strategy is required, Provincial Municipality has a decent city/district as a place for children to grow, play, and clean for children, be it at home, school, and community, and also to guarantee the use of children rights. For that, needed a responsibility with different models from error collaboration and partnerships for interaction and rapid growth in development policy/program.

Collaborative planning, as proposed by Friedman (2011), corrects on transactive planning, including communications made between multiactors. The process of togetherness will work well if there is communication in the form of keyword dialogue in it. In the context of transactive planning, the dialogue is the dialogue of life, which Innes \& Booher (2000) emphasize as the authentic dialogue. Every actor who co-exists appreciates each other, has empathy, and gains benefits mutually. Thus, a dialogue will only happen if the stakeholders are together in facing the problem. The participation itself will only happen if they have a purpose and have the opportunity to voice their interests, and the role will only happen if there are interdependence and trust. Cooperation through dialogue and participation refers to the formation of consensus (Woltjer, 2000). Collaborative Planning begins with planting a dialogue between stakeholders (actors) by combining the following processes: 1 ) Identifying problems, 2) Identifying stakeholders, 3) Building trust, 4) Building a shared understanding, 5) Generating joint problem-solving efforts and 6) Building a shared commitment. Dialogue similarly aids the process that brings stakeholders both public and private, into joint forums of public institutions, to engage in a decision-making process for consensus (Ansell \& Gash, 2007). Processes that contain dialogue, participation, and orientation for shared outcomes, are summarized in dialogue processes based in multi-stakeholder forums.

The essence of this course of study is to have a proper understanding of the proper areas of urban development. Friedman (2011) also reveals that planning must be at the public level, where necessary activities are taken in social reform, policy analysis, social learning, and social mobilization. The change of address used not only belongs to the government, but also to the actors outside the government. This is the most important point of the study. Meanwhile, Tresiana \& Duadji's research (2017) demonstrated a collaborative urgency in the management of regional development. Meanwhile, Soesanto (2017) sees that with the collaboration model, will be created a development innovation.

This study explains; 1) various central issues of children's problems, support potentials of community institutional, and 2) model structure and phases of acceleration of Child-Friendly city/district that can fulfill children rights, child protection, and child development. 


\section{MeThOD}

The basic concepts that guide this research are 'participative planning' and 'networking' theory as the base of a new paradigm of public administration, called 'governance'.

The method used is qualitative descriptive. There are several basic considerations in choosing this method, that is, the research is not to prove a particular theory, but to verify the interrelationship of (1) the central issue of children's problems, the potentials of community institutional support, (2) the model structure, and (3) acceleration phases of child-friendly cities/districts that are possible to fulfill the rights of children, child protection, and child development, and (4) new meaning, namely substantive explanation obtained in accordance with the views of the actor on the model of childfriendly city/district acceleration.

The data required is the primary and secondary data; both categorized into verbal forms (qualitative data) as well as information in the form of numbers (quantitative data). For that, there are four data collection techniques used. First, observation by direct observation on the site of events and activities undertaken by policy stakeholders and actors as the target of the subject. Second, in-depth interviews with policy stakeholders and selected actors as informants. The informants were chosen intentionally with the criteria: a) directly involved with the KLA program; b) have competence, knowledge, and information; c) activists who have concern for the KLA program; and d) subjects targeted by the KLA program. Third, the Focus Group Discussion (FGD) through focus group discussions on the KLA program's theme by inviting specified informants. This means that the informants specified are also members invited in the FGD, i.e. stakeholder and policy actors, consisting of: (1) 5 academics from the center of women \& children study from National and Private universities in Lampung, 3 members of Lampung Provincial DPRD, 11 members of Lampung Province Regency/Municipal DPRD; 11 people from the District/Municipal PPPA Office in Lampung Province, and 2 from the PPPA Agency of Lampung Province. Fourth, documentation by inventorying various documents, archives, journals, scientific papers, statistics, and other documents from the local government related to the KLA program as well other relevant information. Field research to collect data was conducted in August to November 2017.

The collected data were analyzed using interactive model by Miles \& Huberman (1992) through stages: (1) display data by presenting the research data in the form of tables and verbal descriptions; (2) meaning in accordance with facts that occur on the subject (emic meaning); (3) interpretation by comparing the meaning of emic with the concept or theory which become the foundation, (4) then done the formulation of new concept as finding or commonly called ethic meaning; and (5) to avoid subjectivity bias, which is done by controlling inter-subjects by discussing the meaning of ethic with inter peer group.

\section{RESULTS AND DISCUSSION}

\section{A. Identification of Child Institutional Potential in Lampung Province}

The objective of the child-friendly city development as stated in the Governor's Regulation No. 35/2013 on the Development of Child-Friendly District/City is to integrate the rights of children into district development, to mobilize and integrate the existing human resource, finance, facilities, infrastructure, and methods to the government, the people, and the business community in order to create districts/cities that can fulfill the rights of children. IULA \& UNICEF (2001) describe the prerequisites for KLA development, including 1) the willingness and commitment of regional leaders, as reflected in the regional regulatory documents; 2) available data and basic data systems used for planning, programming, monitoring, and evaluation; 3) the existence of socialization of children rights ensuring the awareness of children rights in children and adults; 4) the existence of child-friendly legal products with the formulation of legislation to promote and protect the rights of children; 5) the availability of a medium to promote activities involving children in programs that will affect them; hear their opinions and consider them in the decision-making process; 6) the existence of programs to strengthen the family's ability to foster and care for children; 7) partnerships and networks in the fulfillment of children's rights and protections; 8) the existence of institutions that coordinate all efforts to fulfill the rights of children. From the above eight prerequisites, Lampung Province has potential to be developed, ranging from the commitment of some local officials in the form of policies, socialization, and participation, as well as various institutions and non-government organizations that are committed to the protection and growth of children.

Some of the potentials that exist and can be developed are as shown in the following table.

Table 1.

Child Policies in Lampung Province

\begin{tabular}{|c|c|}
\hline No. & \multicolumn{1}{c}{ Policy Names } \\
\hline 1 & $\begin{array}{l}\text { Lampung Provincial Regulation No. } 4 \text { of } 2008 \text { on Services } \\
\text { to the Rights of Children }\end{array}$ \\
\hline
\end{tabular}




\begin{tabular}{|c|c|}
\hline No. & Policy Names \\
\hline 2 & $\begin{array}{l}\text { Lampung Provincial Regulation No. } 5 \text { of } 2012 \text { on the } \\
\text { Implementation of Religious and Cultural Education }\end{array}$ \\
\hline 3 & $\begin{array}{l}\text { Lampung Provincial Regulation No. } 10 \text { of } 2013 \text { on } \\
\text { Services and Fulfillments of the Rights of Persons with } \\
\text { Disabilities }\end{array}$ \\
\hline 4 & $\begin{array}{l}\text { Governor of Lampung Regulation No. } 35 \text { of } 2013 \text { on the } \\
\text { Child-Friendly District/City }\end{array}$ \\
\hline 5 & $\begin{array}{l}\text { Governor of Lampung Decree Number G/733/II.11/ } \\
\text { HK/2013 on the Establishment of Working Group for } \\
\text { Children Faced With Legal Cases in Lampung Province in } \\
\text { 2013-2016 }\end{array}$ \\
\hline 6 & $\begin{array}{l}\text { Governor of Lampung Decree No. G/720/II.11/HK/2013 } \\
\text { on the Coordination Forum for Integrated Minimum } \\
\text { Service Standards of Women and Children as Victims of } \\
\text { Violence in Lampung Province } 2013\end{array}$ \\
\hline 7 & $\begin{array}{l}\text { Governor of Lampung Decree No. G/681/B.VII/HK/2011 } \\
\text { on the Establishment of Organizational Structure and } \\
\text { Composition of Telephone is children best friend (TeSA) } \\
129 \text { Lampung Province in 2011-2014 }\end{array}$ \\
\hline 8 & $\begin{array}{l}\text { Governor of Lampung Circular Letter Number } 870 / 2539 / \\
\text { II.11/2013 on Integrated Service to Women and Children } \\
\text { as Victims of Violence in Lampung Province }\end{array}$ \\
\hline 9 & $\begin{array}{l}\text { Governor of Lampung Decree Number G/815/B.VII/ } \\
\text { HK/2013 on the Establishment of a Working Unit for } \\
\text { Holistic Integrative Early Childhood Development of } \\
\text { Lampung Province in 2013-2015 }\end{array}$ \\
\hline 10 & $\begin{array}{l}\text { Cooperation Agreement Between Provincial Government } \\
\text { of Lampung and Regencies/Cities in Lampung Province } \\
\text { No.G/719/B.VII/HK/2013 Dated } 20 \text { September } 2013 \\
\text { about a Cooperation on the Development of Child- } \\
\text { Friendly District/City. }\end{array}$ \\
\hline
\end{tabular}

Source: Duadji, Tresiana, and Putri (2017)

Furthermore, there are several institutions and organizations that have attended and contributed to solving the problems of children in Lampung Province.

Table 2.

Organizations and Institutions of Children in Lampung Province

\begin{tabular}{cl} 
No & \multicolumn{1}{c}{ Children Organizations } \\
1 & $\begin{array}{l}\text { Child Protection Institution (LPA) of Lampung Province } \\
\text { and District/City }\end{array}$ \\
\hline 2 & $\begin{array}{l}\text { Social Activist Association of Children and Poor People of } \\
\text { Lampung HASPAMII }\end{array}$ \\
\hline 3 & $\begin{array}{l}\text { DPP Communication Forum of Nation Children "FKAB" } \\
\text { Lampung Province }\end{array}$ \\
\hline 4 & Lampung Children's Communication Forum (FOKAT) \\
\hline
\end{tabular}

\begin{tabular}{cl} 
No & \multicolumn{1}{c}{ Children Organizations } \\
5 & $\begin{array}{l}\text { Women and Children Service Unit (UPPA) of Lampung } \\
\text { Police }\end{array}$ \\
\hline 6 & Women \& Children R\&D Center, Univ. Lampung \\
\hline 7 & Child Advocacy Institution (LADA) of Lampung Province \\
\hline 8 & $\begin{array}{l}\text { The telephone is Children Best Friend (TESA) 129, } \\
\text { Lampung Province }\end{array}$ \\
\hline 10 & $\begin{array}{l}\text { Integrated Service Center for Women and slow Children } \\
\text { Empowerment Indoman Putri (LIP) }\end{array}$ \\
\hline 11 & $\begin{array}{l}\text { The Institute for Women and Children Empowerment } \\
\text { (LPPA) }\end{array}$ \\
\hline 12 & \begin{tabular}{l} 
PATBM Facilitator \\
\hline
\end{tabular}
\end{tabular}

Source: Duadji, Tresiana, and Putri (2017)

Based on field data and data analysis, this study found that Lampung province has institutional and organizational potentials that have concern for child development. Based on the above table, recorded 12 organizations and institutions for children. When viewed from the side of the process, in addition to institutions that already have the main institutions at the national, provincial, and district/city level, the pattern of institutional formation and organization of children in Lampung Province starts from the early cycle, which is marked by doing share idea and discussion, which is limited for some elites to formulate names, fields, and objectives, and organize the management of the institutions to be formed. Organizational or institutional existence for children moves from activities related to the problems, needs, and daily lives that are truly perceived by society, which is then instituted as a step and effort to strengthen the network, structure building, and institutional existence in the future. The recruitment of new members will be made after the organization has been officially incorporated (notarial deeds), and sometimes the concerned agency does not recruit members, so its practical institutional activities are only for and operated by the core management only.

Villarin, in Gaventa \& Valderrama (1999) on the form of participation argues that organizations or institutions can be important forces in regional development. The emergence of organizational and institutional activities of children has the potential to create networking and partnership of government in solving development issues. Institutions and organizations can also be a medium for mobilizing other community groups. Thus, the mapping of various policy and institutional/ organizational support groups resulted in the 
conclusion that their presence contributed to the change of power in relations between government and non-government actors. The process proves that no power has perfection, so it always requires daily interaction with the mandates to listen to their voices and make their opinions a consideration in decision-making, or even the decision is made together (Tresiana \& Duadji, 2016).

\section{B. Indonesia's Current Regulations on Local Government Accountability: An Overview}

Based on Law Number 23 of 2002 on Child Protection, which is then revised with the amendment of Law no. 35 of 2014, there are 31 (thirty-one) children's rights, namely the rights to (1) play; (2) be creative; (3) participate; (4) relating to parents when separated; (5) free of religion; (6) free to gather; (7) freedom of association; (8) living with parents; (9) survival, growing and developing; (10) the rights to have name; (11) identity; (12) citizenship; (13) education; (14) information; (15) highest standard of health; (16) reasonable standard of living; (17) the rights to personal protection; (18) protection from arbitrary arrest; (19) protection from deprivation of liberty; (20) protection from cruel treatment, punishment and inhuman treatment; (21) protection from physical and nonphysical abuse; (22) protection from abduction, sale, and trade or trafficking; (23) protection from sexual exploitation and sexual use; (24) protection from exploitation/abuse of drugs; (25) protection from exploitation as child labor; (26) protection from exploitation as a remote indigenous minority/ local group; (27) protection from scenery or circumstances which by its nature is not suitable for a child to see; (28) special protection, in emergency/ urgent situations; (29) special protection, as displaced persons; (30) special protection, in the event of a legal conflict; (31) Special protection in armed conflict or social conflict. The presence of both laws above is essential to provide legal guarantees for the protection of children from various acts that harm their rights to (1) survive; (2) grow and develop; and (3) participate and be free from discrimination, violence, exploitation and violence when children are in conflict with the law.

The issues of children that often come to a surface in the implementation of the development in Lampung is illustrated in the following interview quotes. Director of the Institute for Child Protection (LPA) in Lampung Province said: "Violence cases in children are still common in this region. Related to this, during the last three years until 2017, there have been 49 cases of child abuse reported to the community and handled by LPA. Of the 49 cases, 26 cases occurred to junior high school children, 1 case to a senior high school child, and 22 cases occurred to elementary school children. The LPA team found that the perpetrators of violence varied, i.e. parents, peers, teachers at school, and in some cases showed the perpetrators were the neighborhood community where the children lived ". Furthermore, one of the administrators on the Association of Social Activists Care for Children and the Poor of Lampung (HASPAMII) states: "of 13 cases of violence that we advocate, the tendency of abusers are people nearby, that are familiar with the victims and generally they are from the community with middle to low economy and minimal knowledge of gender and moral equality ". While the Director of the Institute for Child Advocacy (LADA) Lampung Province observes: "Based on the experience in handling child abuse cases, we find that the underlying or precipitating violence against children is $25 \%$ due to economic factors, $13 \%$ is due to the lack of knowledge and understanding of the rules and rights of children, $15 \%$ due to the experience and trauma of the perpetrator, and $47 \%$ due to innocence, self-protection, and other factors ".

The issue of children is the domain critical of the local government, but when reviewed, the structure of the budget (APBD) in Lampung Province in 2017 is yet to reflect it, like the conclusion of exposure by the respective government delegates of cities/ districts in Lampung Province during the FGD, i.e. : 1) APBDs derived from RKA-K/L (Action Plans for Ministries / Institutions) of each sub-national government, for children's issues, including childfriendly city/district programs, in which the leading the sector is the PPPA offices, including budget for such activities; 2) the budget value is very small, $10 \%$ of total official budget; and 3 ) other agencies only serve as supporting systems. On this basis, the FDG recommends the need to improve the proportional budget structure based on the issues of children who are interested in their respective regions and the need for integration of programs between SKPD and budget support from each SKPD and other stakeholders to resolve child issues and the acceleration of child-friendly city/district.

The research conducted by Duadji, Tresiana, and Putri (2017) found that there are still many issues concerning children in various fields of development implementation in Lampung Province, as in the following description.

\section{1) Child and Violence}

In Figure 1, the high number of violence in Lampung Province is compared with the students (men 57.4\% and female 45.4\%), between the educational linkage and the dimensions of the individual. Students (elementary, junior, and senior high) are at risk of becoming victims of violence. Junior High School education is a level of education 
that does not yet have independence, where the younger generation has no attitude towards gender inequality and violence. This is the trigger for the victims in junior high school. Furthermore, victims of violence at the college level are quite high for Lampung Province. There are many possible causes: Sex norms that support gender inequalities, ideological acceptance of men, women services and social norms that support violence, weak rejection of violence against women in universities, and weak state institutions/campuses. The establishment of gender norms in universities that support gender is necessary. One of them is through a justified and of gender equality curriculum.

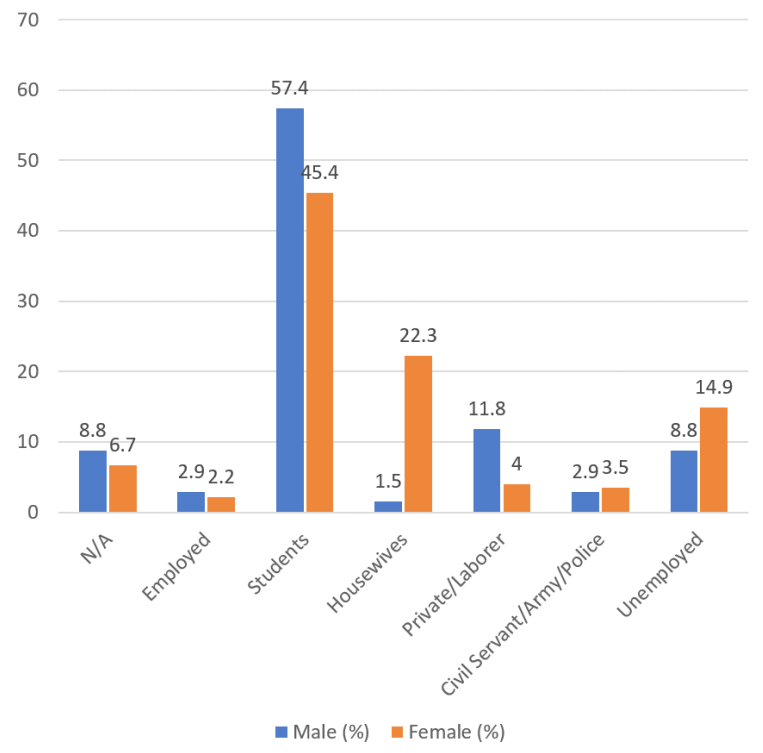

Figure 1. Violence Case Victims in Lampung Province Based on Profession

\section{2) Child Against the Law (ABH)}

The total number of children facing the law in Lampung Province in 2016 reached 230 children, which are found and spread in 11 districts/cities. Bandar Lampung City and North Lampung District have a relatively high number of $\mathrm{ABH}$ compared to other regions. The number of $\mathrm{ABH}$ in Bandar Lampung reached 78 people $(33.9 \%)$ in total. Meanwhile, the number of $\mathrm{ABH}$ in Lampung north reaches 54 children $(23.5 \%)$. The number of female $\mathrm{ABH}$ in Bandar Lampung is even higher than that of the male. The number of female $\mathrm{ABH}$ in Bandar Lampung reached 60 people while male $A B H$ is 18 people. The number of female $\mathrm{ABH}$ in East Lampung district is also higher (20 persons) than for male $\mathrm{ABH}$ (8 persons). This phenomenon is somewhat different from the general pattern in which male $\mathrm{ABH}$ is usually more common, and even more dominating, than female $\mathrm{ABH}$.

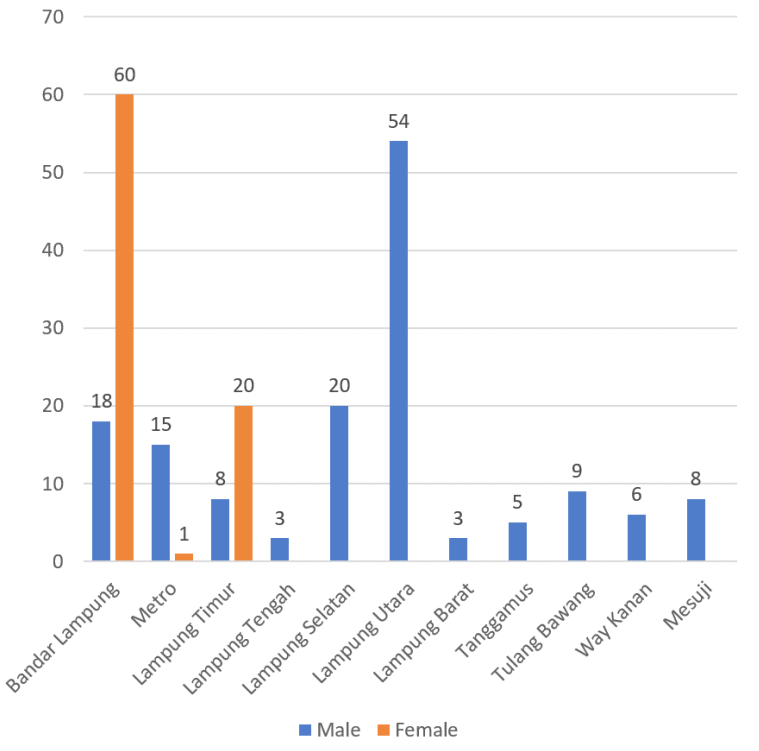

Figure 2. Child Against the Law

\section{3) Child and Social Sector}

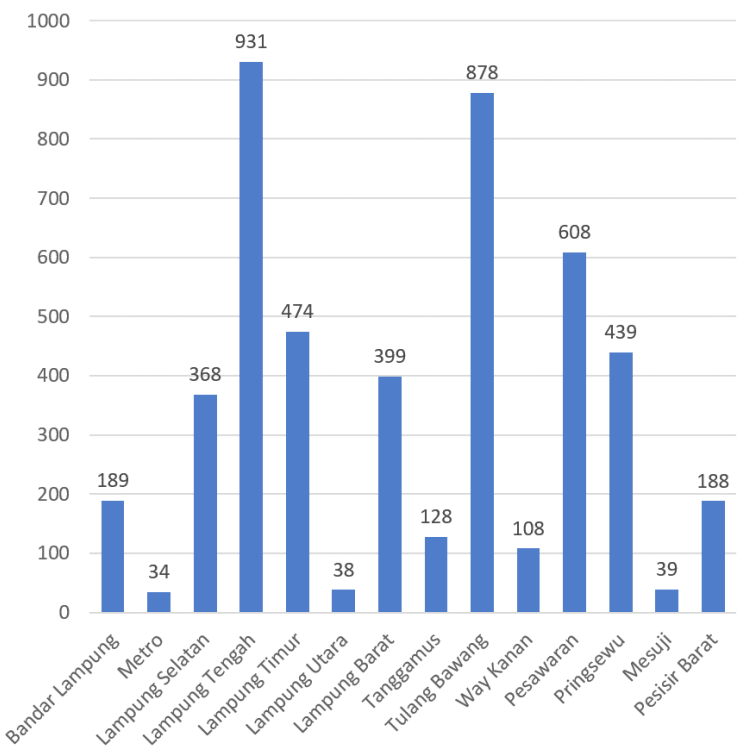

Figure 3. The Distribution of Homeless Toddlers in Lampung Province based on Districts/Cities in 2015

The total number of neglected toddlers in Lampung Province in 2016 reached 4,821 people. The largest number is in Central Lampung District, which is 931 people $(21.7 \%)$. The smallest number is in Metro City, which is 34 people $(0.7 \%)$. This neglected toddler problem reflects the low responsibility of elements of society (government, parents, and society) to the surrounding social problems.

The total number of children with disabilities in Lampung Province in 2015 reached 4.335 people. This data is not yet gender-disaggregated so that the gender gap level is not known. Central Lampung district has the highest number of children with 


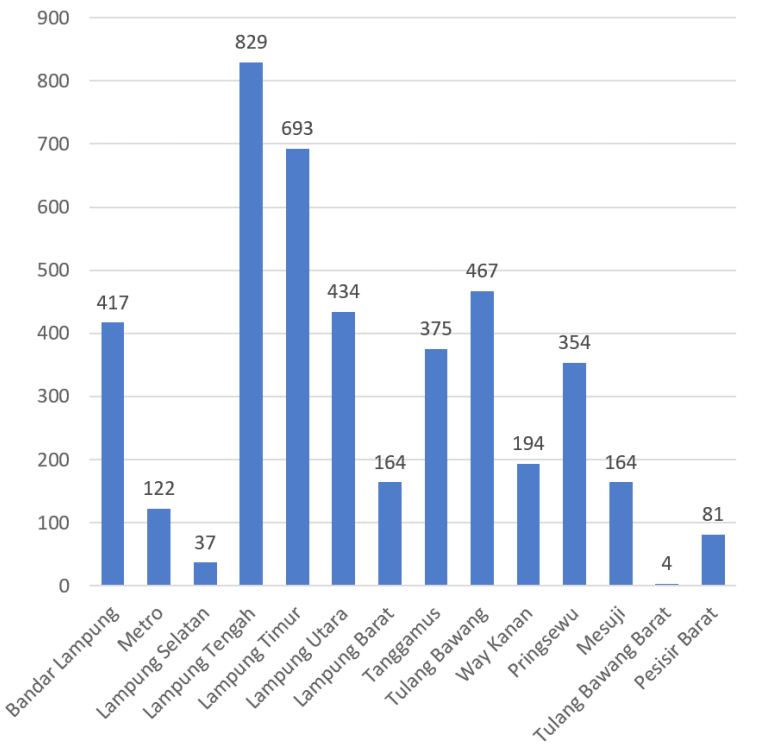

Figure 4. The Distribution of Children with Disability in Lampung Province in 2015 based on Districts/Cities

disabilities, which is 829 people, and Tulang Bawang Barat district is the district with the smallest number of persons with disabilities, which is 4 people.

\section{4) Child and Health}

The data on infant mortality in Lampung Province in 2016 is as many as 627 children. The district with the highest number, in this case, is Central Lampung (86 cases), while the lowest district is West Lampung (9 cases). Other districts with a relatively high number of cases are Tanggamus (70 cases), Pringsewu (69 cases), South Lampung (59

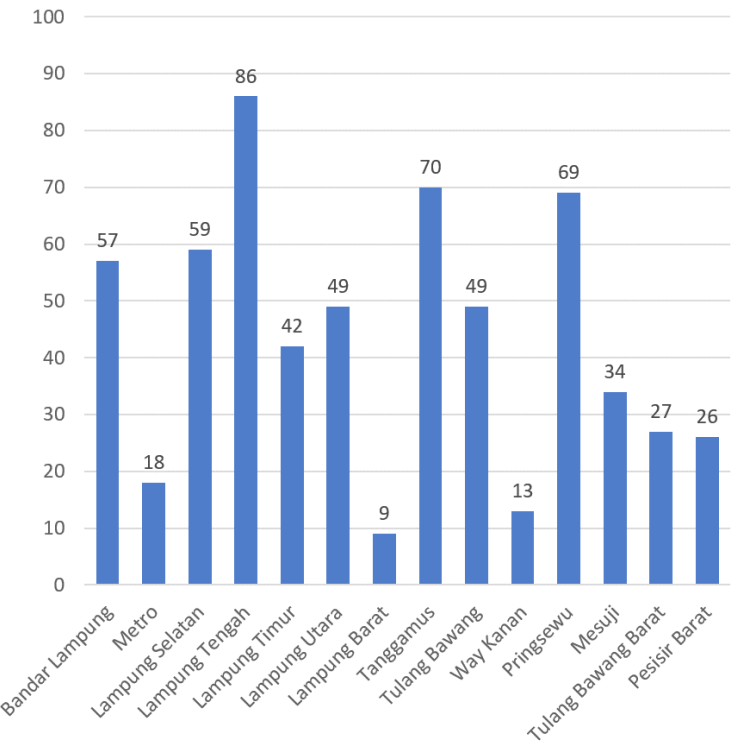

Figure 5. The Data of Infant Mortality in Lampung Province, 2016

cases), and Bandar Lampung (57 cases). Meanwhile, the districts with a relatively small number of cases are West Bone (27 cases), Pesawaran (19 cases), Metro City (18), and Way Kanan (13 cases).

Overall, toddlers who got complete immunization in Lampung Province in 2016 reached $60.4 \%$. There is a difference (disparity) between male and female toddlers who got a complete immunization. Female toddlers reached $61.5 \%$, while toddlers only $59.2 \%$. In other words, the disparity reached $2.3 \%$. However, this pattern is uneven for all regencies in Lampung Province. Pesisir

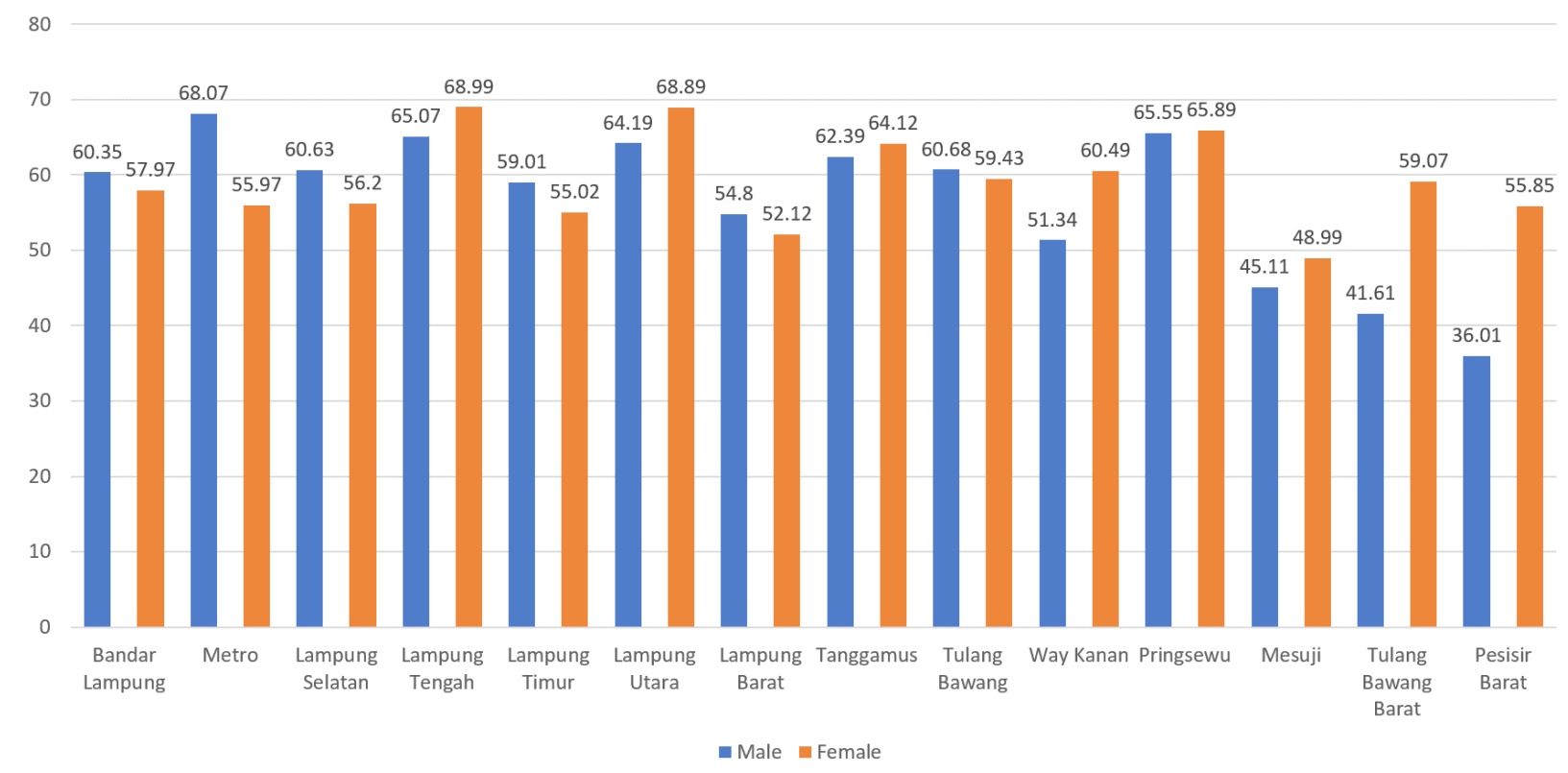

Figure 6. Percentage of Toddlers with Complete Immunization based on Gender in Lampung Province Districts/Cities in 2016 
Barat District is the highest district with 19.84\%, followed by Tulang Bawang Barat with $17.46 \%$, and Way Kanan (9.15\%). Meanwhile, districts, where the percentage of male toddlers' immunization is higher than female toddlers, are Lampung Barat (2.68\%), South Lampung (4.43\%), East Lampung (3.99\%), Pesawaran 1.25\%), Pringsewu (0.01), and Bandar Lampung City (2.38).

Referring to Figure 6, Lampung Province still shows some indications that children's rights have not been met optimally. Problems that arise include: 1) The high number of violence against children; 2) There are still many children who face legal issues, which are often lacking in their rights; 3) The low level of health services; 4) still found the existence of deficient and bad nutrition, and social problems of children and other things that are still often encountered.

The local government itself has sought to improve the quality of children by implementing the Mainstreaming of the Children Rights (hereinafter called PUHA), a strategy to integrate the issues and rights of the child into each stage of development from planning, implementation, monitoring, legislation, policies, programs and activities, as well as budgets, by applying the principle of the best interests for children. This strategy is a manifestation of the paradigm shift from the previous partial, segmented, and sectoral development into holistic, integrative, and sustainable.

The mapping of the child's problems above shows a child's composition and behavior patterns that are closely related to the treatment or policies of various parties, such as the Government, Parents, as well as certain Institutions, to the children. Based on the data in the field, there are some things that become important findings, namely 1) Child development data has not shown significant progress; 2) The Law on Child Protection, although it has received attention, the realization of programs and activities must be achieved immediately; 3) The successful achievement of child protection development in the field of education, which involves many stakeholders, can be used as a reference and entrance for enhancing wider child protection.

\section{Collaborative Planning Model in KLA Acceleration}

The acceleration model of child-friendly city/ district is run by actors who should be synergic and intersectional, i.e. the public/government sector, the private/business sector, and the non-profit/ non-governmental sector. The emergence of the Collaborative Planning model is a new trend that emphasizes partnerships, creativity, drive, and talent as the solutions to child problems. The relationship between Collaborative Planning and children's programs is a strategic area to explore. Based on empirical data, Collaborative Planning begins with a dialogue between stakeholders (actors) with the following set of processes: 1) Identifying problems, 2) Identifying stakeholders, 3) Building trust, 4) Building a shared understanding, 5) Generating problem-solving efforts together, and 6) Building a common commitment. A dialogue emphasizes a process that brings stakeholders, both public and private, into a common form of public institutions, to engage in consensus-oriented decision making (Ansell \& Gash, 2007).

The determination of Collaborative Planning model, which basis is dialogue in a multistakeholders forum, is based on field findings, namely: 1) there are still many problems of children that must be responded in development, such as issues of children in the field of health, violence, disability, law, and social issues; 2) the potential for support for the development of child-friendly city/district policy, ranging from various child support policies and the presence of child service providers, in the form of community institutions and community organizations in Lampung Province. Based on the data obtained from interviews, observation, and FGD, it is found that the important aspects in collaborative planning as a determinant of acceleration in child-friendly city/district are; 1) the main prerequisite phase in the establishment, 2) the phase of technical implementation, 3) the monitoring and evaluation phase.

The first phase, the main prerequisite phase, must meet the following key prerequisites: 1) The existence of a rights-based approach to thinking by the proponent and managers of the child's program

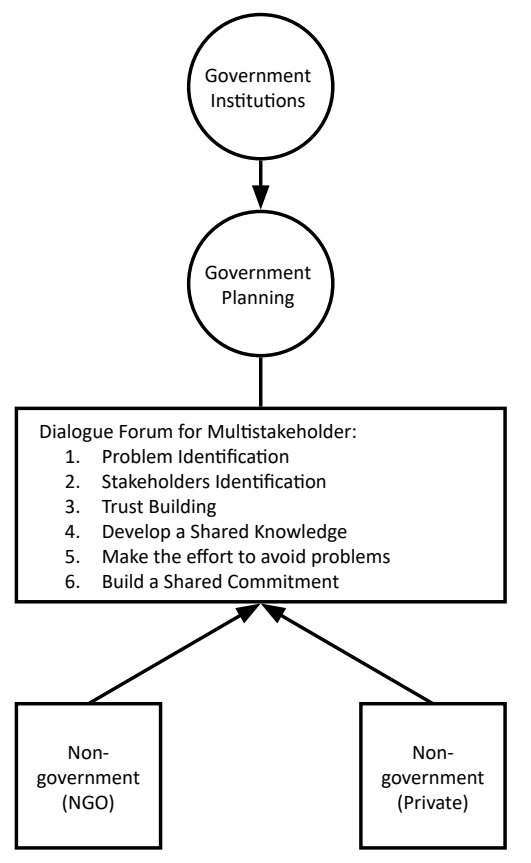

Figure 7. Model of Collaborative Planning KLA 

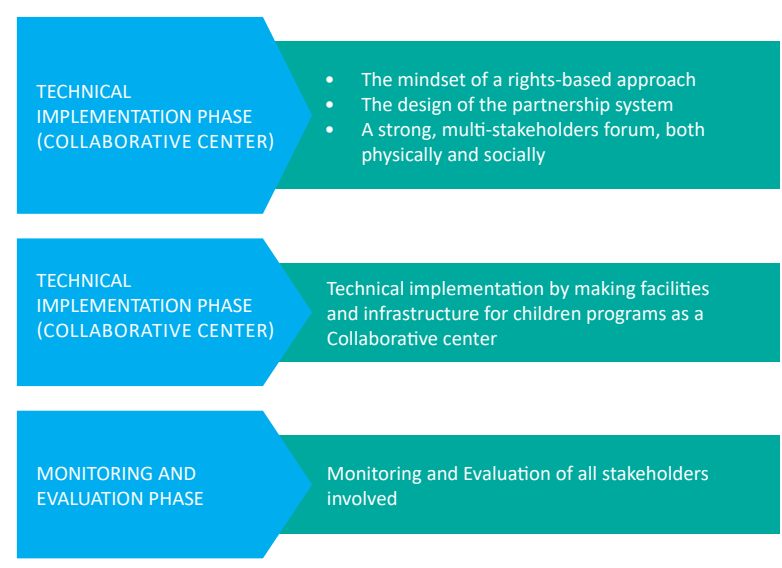

Figure 8. Phase and Area of Collaborative Planning in KLA

as a major group or group of persons who have the rights to express their opinions in the best interest and self-development; 2) The design of partnership system by involving stakeholders in accordance with their respective roles and functions. The widest possible partnership involves all parties in the City; 3) There is a strong community forum as a community center. The second phase is the phase of technical implementation, as well as a community center through the creation of real programs for children. The third phase is the monitoring and evaluation phase, where all stakeholders should be involved in the monitoring and evaluation of the child's program. Each stakeholder needs to do so in accordance with their respective capacities. There is a need for a major instrument for monitoring and evaluation, which includes short, medium, and longterm evaluations.

\section{ConClusion}

In accordance with the objectives of the study, this study successfully mapped the problems of children that often appear in Lampung Province: 1) The high number of violence against children; 2) the number of children dealing with legal issues and the lack of childcare services in prisons; 3) low child health services; 4) bad and lack of nutrition; and 5) lack of service facilities for children with special needs.

The mapping also found that there are potentials of community institutions that have concerns about child issues and local government policy support, but both are not synergic, development programs are still implemented partially, segmented, sectorally, not yet integrated, lack of involvement or inclusion on the potential of the community. This result becomes a reference material that Lampung Province still requires more steps and efforts to encourage the realization of Child-Friendly district/city. Thus, at least the Provincial Government of Lampung can initiate a step in two main domains. First, to provide a space for all the elements of society, the private sector, and other NGOs to participate in preparing the infrastructure (sapras) for Child-Friendly City/ District in their respective environments. Second, establishing multi-stakeholders forums to be actively involved in regional development planning, especially with regard to the KLA program.

To overcome the problem of children and accelerate the realization of the Child-Friendly program in Lampung Province, the Collaborative Planning Model of dialogue base in multistakeholders forum is a solution that can be implemented by each city/district government, including Lampung Provincial Government, because this model emphasizes partnership, creativity, drive, and potential exploration and more children's talents become more on the focus. The relation between Collaborative Planning and children's programs is a strategic area as a solution to Child-Friendly city/ district through the implementation of 3 phases that become KLA acceleration area/structure in the prerequisite phase (perspective, partnership, and forum/community), the community center, and monitoring and evaluation phase.

\section{ACKNOWLEDGEMENT}

The author would like to thank Peergroup Public Policy Department of Public Administration Fisip Unila, Research Team of Research and Development Center for Women, Children, and Development of LPPM Unila. The authors especially would like to thank the Institute for Research and Community Service that has provided Skim Research Excellence Grant PT. This paper is the result of 2017 PT Excellence research.

\section{REFERENCES}

Ansell, C., \& Gash, A. (2007). Collaborative Governance in Theory and Practice. Journal of Public Administration Research and Theory, 18(4), 543-571. http://doi.org/10.1093/ jopart/mum 032

Bakar, H. A. (2017). Pemetaan Pusat Pelayanan Terpadu Pemberdayaan Perempuan dan Anak (P2TP2A) Provinsi Sumatera Barat. Kafa'ah: Journal of Gender Studies, 7(1), 107. http://doi. org/10.15548/jk.v7i1.168

Duadji, N. (2017). Model Percepatan Kota Layak Anak. Laporan Penelitian Hibah Penelitian Unggulan Perguruan Tinggi. Lampung, Indonesia.

Duadji, N., \& Tresiana, N. (2017). Kota Layak Anak yang Berkelanjutan. Bandar Lampung: Aura Press.

Friedman, J. (2011). Insurgencies, Essay in Planning Theory. London \& New York: Routledge.

Gaventa, J., \& Valderrama, C. (1999, June). 
Participation, Citizenship and Local Governance. Background Note Prepared for Workshop on ?Strengthening Participation in Local Governance?. Institute of Development Studies.

Hamudy, M. (2015). Upaya Mewujudkan Kota Layak Anak di Surakarta dan Makassar. Jurnal Bina Praja, 7(2), 149-160. http://doi. org/10.21787/JBP.07.2015.149-160

Innes, J. E., \& Booher, D. E. (2000). Beyond Collaboration: Democratic Governance for a Resilient Society. In Planning with Complexity: An Introduction to Collaborative Rationality for Public Policy. Routledge.

IULA (International Union of Local Authorities, \& UNICEF (United Nations Children's Fund). (2001). Partnerships to Create Child-Friendly Cities: Programming for Child Rights with Local Authorities. Florence: UNICEF.

Lynch, K. (Ed.). (1977). Growing up in Cities: Studies of the Spatial Environment of Adolescence in Cracow, Melbourne, Mexico City, Salta, Toluca, and Warszawa. Cambridge, MA: MIT Press.

Mahendra, G. K. (2017). Analisis Implementasi Kebijakan Kota Layak Anak Bidang Kesehatan Ramah Anak. Journal of Health Studies, 1(2), 95-104. Retrieved from https://ejournal. unisayogya.ac.id/ejournal/index.php/JHeS/ article/view/245

Miles, M. B., \& Huberman, A. M. (1992). Analisis Data Kualitatif. Jakarta: UI Press.
Sari, S. R. (2015). Membangun Kota Ramah Anak dengan Budaya Kota Berserambi Baca. Jurnal Sosial Budaya, 12(2), 215-224. Retrieved from http://ejournal.uin-suska.ac.id/index.php/ SosialBudaya/article/view/1942

Soesanto, H. (2017). Development of Innovation Project as the Result of Leadership Training Through the Innovation Actor Collaboration Model in the Region. Jurnal Bina Praja, 9(2), 335-343. http://doi.org/10.21787/ jbp.09.2017.335-343

The CFC Initiative. (2011). Retrieved October 27, 2014, from http://www.childfriendlycities. org/en/overview/the-cfcinitiative

Tresiana, N. (2015). Perumusan Kebijakan Pendidikan yang Berperspektif Gender di Provinsi Lampung.Jurnal Borneo Administrator, 11(2). http://doi.org/10.24258/jba.v11i2.192

Tresiana, N., \& Duadji, N. (2016). Multi Stakeholders Governance Body Model In Achieving the Excellence Public Policy. MIMBAR, Jurnal Sosial Dan Pembangunan, 32(2), 401. http://doi. org/10.29313/mimbar.v32i2.1879

Tresiana, N., \& Duadji, N. (2017). Model Pengembangan Pengelolaan Pariwisata Berbasis Komunitas. Laporan Penelitian Produk Terapan Kemenristekdikti Tahun Anggaran 2017. Bandar Lampung, Indonesia.

Woltjer, J. (2000). Consensus Planning: The Relevance of Communicative Planning Theory in Dutch Infrastructure Development. Ashgate. 